\title{
Effect of Socio-Economic Factors on Growth of Butchery Enterprises in Nyamira Town, Kenya
}

\author{
Robert Mwaniki Momanyi ${ }^{1}$ (JKUAT Kisii CBD Campus), Dr. Willy Muturi ${ }^{2}$ (Jomo \\ Kenyatta University of Agriculture and Technogy) \& Dr. Charles Munene Elijah ${ }^{3}$ \\ (Masai Mara University)
}

\begin{abstract}
The dynamic role of micro and small enterprises (MSEs) in developing countries as engines through which the growth objectives of developing countries can be achieved has long been recognized. The purpose of this study was to establish the effect of socio-economic factors on growth of butchery enterprises in Nyamira Town, Kenya. The specific objectives of this study were: to establish the effect of capital on growth of butchery micro-enterprise; to determine the effect of accounting skills on growth of butchery micro-enterprise; to find out the effect of accessibility to credit on growth of butchery micro-enterprise and to assess the effect of market information on growth of butchery micro-enterprise in Nyamira Town. This study is anchored on Jovanovic's Learning Effect Model. This study adopted a descriptive survey design. The study also targeted respondents drawn from Sub-County Development Officers (SCDO), and trade officers. According to the registry of businesses in Nyamira town by the county council, there about 80 butchery enterprises in this region, ISCDO and 1 trade officers. In this study, simple random sampling was used to select 47 butchery proprietors from the 80 butchery enterprises which the researcher considered to be representative sample because the sample size. Purposive sampling was used to select the SCDO and Trade officer as key informants in the study. The researcher used questionnaires, personal interviews and observation schedules as tools for collecting data. The reliability of the instruments the researcher conducted a pilot study in the butcheries in the neighbouring Kisii Town in Kisii County with a coefficient of 0.895 was obtained implying that there was a high degree of reliability of the data. Quantitative data was analyzed through frequency distribution and percentages and presented in tables and figures, graphs and pie charts. Qualitative data was analyzed by use of content analysis or descriptive method. Based on the findings the researcher found that majority of the butchery owners in Nyamira Town face a lot of socio-economic challenges, which could be responsible for their dwindling growth rate. Some of these challenges were found to be inadequate starting and working capital, inaccessibility of both financial and credit facilities to expand their businesses. The study also established that most of the butchery owners were not accessing credit facilities due to high interest rate change, high collateral required and complicated procedures in loan application. The government through the ministry of trade, finance and planning should use the findings of this research as a platform in designing the policies and measures that when implemented would govern promote the stability and sustainability of not only the butchery micro-enterprises, but other small scale business enterprises.
\end{abstract}

Key words: Butchery micro-enterprises, Capital, Accounting skills, Credit, Market information

\section{Introduction}

All business ventures regardless of size require finances from inception and throughout their life cycles. The amount invested will influence greatly the size of the venture, which in turn determines the early survival of an enterprise if other factors are held constant. The entrepreneur will require seed capital to start the business, to operate and manage the business enterprise. Orser (2000) noted that unavailability or lack of information about alternative sources of finances and inability of SMEs to evaluate financing option were some of the major problems facing the SMEs. Mambula (2002) singled out lack of access to finances as the main bottleneck facing MSE growth which was similarly echoed by Florida et al, (1996) and Livard Pang (2006) who found that start-up capital is a barrier to entry in most entrepreneurial activities and that lack of capital was cited by $80 \%$ of all respondents as the greatest start-up problem.

According to OAS (2001), lack of access to credit is almost universally indicated as a key problem for SMEs. This affects technology choice by limiting the number of alternatives that can be considered. In some cases, even where credit is available, the entrepreneur may lack freedom of choice because the lending conditions may force the purchase of heavy, immovable equipment as collaterals. Credit constraints operate in variety of ways in Kenya where undeveloped capital market forces entrepreneurs to rely on self-financing or borrowing from friends or relatives. Lack of access to long-term credit for small enterprises forces them rely on very expensive short term loans. There are other financial challenges that face small enterprises. They include the high cost of credit, high bank charges and fees. 
Eshetu and Zeleke (2011) conducted a longitudinal study to assess the impact of influential factors that affect the long-term survival and viability of small enterprises by using a random sample of 500 MSMEs from 5 major cities in Ethiopia. According to this research, which lasted from 2006 to2011, the factors that affect the long term survival of MSMEs in Ethiopia are found to be adequacy of finance, level of education, level of managerial skills, level of technical skills, and ability to convert part of their profit to investment. This is so because the findings of the study revealed that businesses that failed, during the study period were characterized by inadequate finance (61\%), low level of education (55\%), poor managerial skills (54\%), shortage of technical skills $(49 \%)$, and inability to convert part of their profit to investment (46\%). The study further indicated that participation in social capital and networking schemes was critically helpful for long-term survival of the enterprises. Businesses that did not participate in schemes regularly were found to be 3.25 times more likely to fail in comparison with businesses that did, according to the study. In another study, based on the survey covering 123 businesses units in four Kebeles of Nifas Silk- Lafto and Kirkos sub-cities of Addis Ababa, and aimed to investigate the constraints and key determinants of growth, particularly in employment expansion, Paul and Rahel (2010) found out that the concrete problems that the targeted MSEs faced at their startup were lack of capital (52.8\%), skills problem (17.9\%) and lack of working space (17.1\%). Moreover, Daniel (2007) identified that lack of raw material, stiff competition and shortage of working capital as one of the major impediment to growth of SMEs in Ethiopia. Jitihada (2010), states that the scenario witnessed in Kenya particularly during the climaxing period of the year 2008 testifies the need for credit among the common and low earning entrepreneurs, given that adequate working or starting capital is a major challenge to such business enterprise

As is mostly the case and common recognition, "Competition is Cruel", which implies that some larger companies in relation to MSEs have advantages due to: selling at reduced price without reducing product quality using economies of scale, customer targeting capacity, proper and intensified product/service advertising capacity, good personal contacts and networks, sound industry reputation and sufficient information regarding existing market and capacity to exploit more market opportunities. Assegedech (2004) justifies this in his study when he found that competition is also one of the hindrances for growth and sustainability of SMEs in Malawi.

In his research, Dereje (2008) studied the nature, characteristics, economic performance, opportunities and challenges of MSEs in the food vending sector based on 125 sample enterprises. The results of the study revealed that the main constraints of these MSEs were shortage of capital, absence of government support, lack of market, lack of credit facilities and high interest rate. Studies were also conducted specifically with a purpose of identifying the problems that MSEs encounter. For instance, Workneh's (2007) research undertaken in one of the sub-cities of Ghana indicated that lack of capital, lack of market, unfavorable policy, and inadequate infrastructure, absence of adequate and relevant training, bureaucratic structure and procedures are among constraints faced by MSEs. Similarly, Adil's (2007) research carried out in South Africa shows that inappropriate government intervention, shortage of capital, location disadvantage, lack of market and lack of display room are the major challenges that obstruct the growth of MSEs in this country.

Change of technology has posed a great challenge to small businesses. Since the mid 1990s, there has been a growing concern about the impact of technological change on the work of micro and small enterprises. Even with change in technology, many small business entrepreneurs appear to be unfamiliar with new technologies. Those who seem to be well positioned, they are most often unaware of this technology and if they know, it is not either locally available or not affordable or not suited to local conditions, (Gancia et al 2005). Foreign firms remain in the forefront in accessing the new technologies. In most of the African nations, Kenya inclusive, the challenge of connecting indigenous small enterprises with foreign investors and speeding up technological upgrading still persists, (Muteti 2005). There is digital divide between the rural and urban Kenya. With no power supply in most of the rural areas, it is next to impossible to have Internet connectivity and access to information and networks that are core in any enterprise. Thus technological change, though meant to bring about economic change even among the rural lot, does not appear to answer to the plight of the rural entrepreneurs.

Muteti (2005) argues that lack of sufficient market information poses a great challenge to small enterprises. Despite the vast amount of trade-related information available and the possibility of accessing national and international databases, many small enterprises continue to rely heavily on private or even physical contacts for market related information. This is due to inability to interpret the statistical knowledge that could interpret and inter connect small enterprises entrepreneurs need to be supported. With connectivity, being enhanced (by connecting Kenya globally through Fiber Optic project) there is renewed hope for the SMEs.

\section{Statement of the Problem}

According to Irwin (2004) governments all around the world now recognize the important contribution that small firms make to the economy and many governments have established extensive support arrangement to help people start and grow their businesses. In Kenya, $70 \%$ of small-scale enterprises are located in the rural areas and they have a high potential of contributing to rural economic development. Despite the support and 
incentive programs to small scale business, Akabueze, (2002) succinctly stated that it would seem reasonable to expect that small businesses would grow and flourish, but the rate of business failure continues to increase because of the obstacles affecting business performance. Some researches into small-business development have also shown that the rate of failure of small scale businesses in developing countries is higher than in the developed world (Marlow, 2009). More astonishing, despite the existence of micro-finance and promotion of value addition, butcheries in Nyamira Town have limited value addition to the locals in terms of employment opportunities if they added value to their products. They have rather performed below set targets in Kenya (ROK, 2005). This study therefore, sought to find out the effect of socio-economic factors on growth of butchery micro-enterprises in Nyamira Town with a view of improving the Kenyan economy to be in line with the Vision 2030.

\section{Specific objectives of the study}

The study employed the following specific objectives:

i. To establish the effect of capital on growth of butchery micro-enterprise in Nyamira Town.

ii. To determine the effect of accounting skills on growth of butchery micro-enterprise in Nyamira Town.

iii. To find out the effect of accessibility to credit on growth of butchery micro-enterprise in Nyamira Town.

iv. To assess the effect of market information on growth of butchery micro-enterprise in Nyamira Town.

\section{Justification of the study}

This study highlighted the socio-economic factors affecting the growth of butchery micro-enterprises in Nyamira town and gave possible recommendations policies and measures of enhancing their growth. Therefore, the findings of this study may be of help to micro-business entrepreneurs such as butchery owners so that they could use the findings of these study as an avenue for equipping themselves with information on factors affecting the growth of their business enterprises and if need be, based on the study's recommendations, work on these challenges and promote growth and sustainability of their businesses. Moreover, butchery operators should be made aware of the available financial sources and the costs involved and, are encouraged to undergo hospitality management courses to improve their skills in management. The findings could assist the government in designing the policies and measures that when implemented would govern not only the butchery micro-enterprises, but also other small-scale business enterprises, with a view of promoting their growth and sustainability. The findings of this study may help the academia in formulating new theories in relation to the growth and sustainability of micro-business enterprises and their contribution to the nation's economy. Moreover, any future researchers may use the recommendations and conclusions that will be made in this study to aid them on the direction on which to base their future research.

\section{Scope of the study}

The study covered only the registered butchery micro-enterprises in Nyamira Town, leaving other forms of micro-businesses. Based on duration, the study took only three months, as from October 2012 to December the same year. With respect to the respondents, the study only focused on the proprietors of the butchery enterprises, Trade Officer and Sub-County Development Officer (SCDO) in Nyamira district. The areas of concern assessed were: to establish the effect of capital on growth of butchery micro-enterprise; to determine the effect of accounting skills on growth of butchery micro-enterprise; to find out the effect of accessibility to credit on growth of butchery micro-enterprise and to assess the effect of market information on growth of butchery micro-enterprise in Nyamira Town.

\section{Theoretical Framework}

This study is anchored on Jovanovic's Learning Effect Model. Jovanovic's model was constructed the model in 1982 and it asserts that firms learn about their efficiency and growth overtime. New firms entering the market are unaware of their true efficiencies immediately but as they mature, they are able to uncover their productive efficiencies (Staines, 2005). Empirical implication derived by this model is that young or microbusiness ventures such as butchery enterprises have accumulated less information than older ones about their managerial abilities. For this reason there will be more exists among young firms than older firms. These postulations are also supported by entrepreneurial choice theory (Papadaki \& Chami, 1982). According to entrepreneurial choice theory, people have certain characteristics that are associated with the propensity for entrepreneurial behaviour. Individuals who have more of these characteristics are more likely to grow faster than those who have fewer ones (Papadiki \& Chami, 2002). In other words the attitude of the individual in taking risks, motive of going into self employment, his or her managerial abilities to raise capital and perceive new markets, will determine the growth of the firm. Jovanovic's Learning Effect Model and entrepreneurial choice theory (Papadaki \& Chami, 1982) can best be illustrated using the life cycle models, which aim at explaining the growth of an enterprise using the biological metaphor of the "life-cycle". 
According to McMahon (1998) postulates that "Organizations are born, grow and decline. Sometimes they reawaken, and sometimes they disappear"

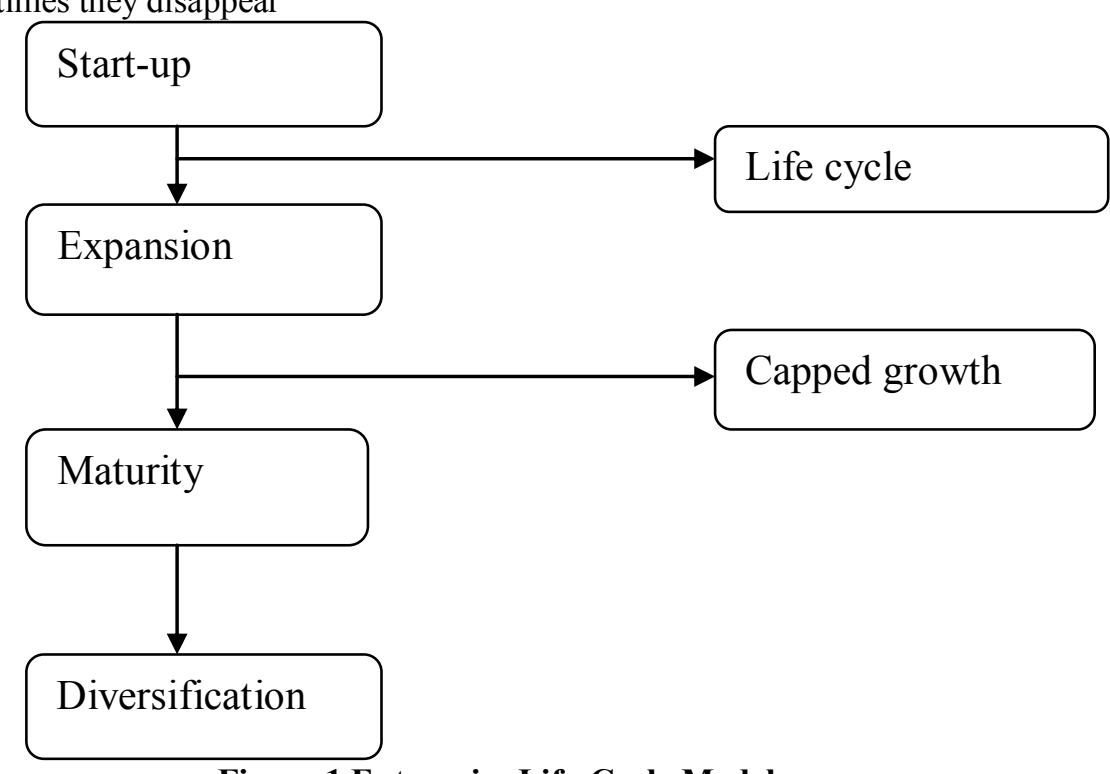

Figure 1 Enterprise Life-Cycle Model

According to this model of the enterprise life-cycle, important changes occur to firms as they grow from one level to the other. This assumes S-shaped growth pattern that shows a slow growth in the early development then followed by a rapid growth, before slowing down again, (Schmitt-Degenhardt et al., 2002). At each stage of the process, the small firm can grow, plateau or even die. Whereas the life-cycle of the enterprises can be seen as a progression from smaller to larger firms as it passes from start-up, expansion through diverse stages, some firms do disengage from the growth trajectory of the life cycle. The two disengagement stages are lifestyle and capped growth. In the case of lifestyle firms, the concerns generally have few if any growth aspiration; they principally exist to provide their owner managers with a source of employment and income. Therefore, as long as the owner managers of these firms earn a living, there is no real reason why they should grow in size. Capped growth on the other hand refers to those firms that do not grow to where formal organization, financing and management practices are required (SIEID, 2004). This is usually the result of a conscious and deliberate decision by the owner-manager to restrict the firms expansion out of a desire to avoid risk, minimize surrender of control, uncertainty and the general problems associated with hiring more employees, winning new markets, developing new products or securing new capital investments.

\section{Methodology}

This study adopted a descriptive survey design. Descriptive survey designs are used when the objective is systematic or description of facts and characteristics of a given population or sample of the population or area of interest factually and accurately, (Kothari 2007). It gathers data at a particular point in time with the intention of describing the nature of the existing conditions, identifying the standards against which existing conditions can be compared and determining the relationship that exists between specific events, (Kombo \& Delno, 2006). Survey research design was used because the population under study was too large to observe directly and this enabled the researcher to use questionnaires as a method of data collection.

The primary target population for the quantitative data was the licensed butcheries run by proprietors. The study also targeted respondents drawn from Sub-County Development Officers (SCDO), and trade officers. These were chosen as they were in the running and development of the butcheries. According to the registry of businesses in Nyamira town by the county council, there about 80 butchery enterprises in this region, 1SCDO and 1 trade officers. These formed the sample frame for the study.

In this study, simple random sampling was used to select 47 butchery proprietors from the 80 butchery enterprises which the researcher considered to be representative sample because the sample size was large enough containing all the variation in the population and equal and independence chance was given to each individual in the population to be selected. Purposive sampling was used to select the DDO and Trade officer as key informants in the study. 
According to Nassiuma (2000), the sample size of the butchery proprietors can be determined by the following formula:

Where $n=$ Sample size

$$
\mathrm{n}=\mathrm{NC} \mathrm{C}^{2} /\left(\mathrm{C}^{2}+(\mathrm{N}-1) \mathrm{e}^{2}\right)
$$

$\mathrm{N}=$ Population

$\mathrm{C}=$ Coefficient of variation of 0.21 .

$\mathrm{e}=$ Standard error of 0.02 .

The calculated sample size is represented as in table 1.

Table 1: Population sample and sample size

\begin{tabular}{lll}
\hline Participants & Population Sample (N) & Sample Size (S) \\
Butchery Proprietors & 80 & 47 \\
DDO & 1 & 1 \\
Trade officer & 1 & 1 \\
Totals & $\mathbf{8 2}$ & 49 \\
\hline
\end{tabular}

The researcher used questionnaires, personal interviews and observation schedules as tools for collecting data.

The pilot test was done to determine the reliability and validity of the research instruments before being used for data collection. In order to establish the reliability of the instruments the researcher conducted a pilot study in the butcheries in the neighbouring Kisii Town in Kisii County. The area was used because the two counties have near similar conditions and are in the lake region. The research instruments were administered to the pilot group and a coefficient of 0.895 was obtained implying that there was a high degree of reliability of the data.

To assess the content validity of the questionnaires and interview schedules the researcher sought supervisory assistance of experts in the field of Entrepreneurship, School of Human Resource Development, Jomo Kenyatta University of Agriculture and Technology. They assessed them and gave the required feedback for implementation. Through this, the researcher was able to identify loopholes in them and made the necessary adjustments.

The study collected and analyzed both quantitative and qualitative data. Quantitative data was analyzed through frequency distribution and percentages and presented in tables and figures, graphs and pie charts. Qualitative data was analyzed by use of content analysis or descriptive method.

\section{Results and Discussion}

The concern of this study was to establish the effect of the socio-economic factors on growth of butchery enterprises in Nyamira Town. The responses are as follows:

i. Daily Expenses to accumulative monthly expense of Ksh.1000-5000

Table 2: Daily Expenses to accumulative monthly expense of Ksh.1000-5000

\begin{tabular}{lcc}
\hline Recurring expenditure & Frequency & percentage \\
Transport & 1 & 2.22 \\
Health care & 1 & 2.22 \\
Entertainment/leisure & 2 & 4.44 \\
Family food and basic needs & 20 & 44.44 \\
Business premise rent & 11 & 24.44 \\
Family house rent & 10 & 22.22 \\
TOTAL & $\mathbf{4 5}$ & $\mathbf{1 0 0}$ \\
\hline
\end{tabular}

As part of socio-economic factors, respondents were asked to indicate the type of recurring expenses they incurred to a monthly cumulative of between Ksh.1000-5000. Out of the 45 respondents that took part in answering this question, majority of the respondents at $44.44(20) \%$ indicated Family Food and basic needs, 24.44\%(11) mentioned Business premise rent, 2.22\%(1) cited Health care and transport each, 22.22\%(10) indicated family house rent, $4.44 \%(2)$ mentioned entertainment. This shows that most of the butchery owners are also faced with challenges revolving around their family welfare, which also weigh down their business growth.

\section{ii. The business is facing Socio-Economic Challenges}

The study sought to investigate whether the butchery businesses were facing any challenges then. Out of the 45 respondents who took part in the study, majority at $67 \%$ disclosed that their businesses were facing challenges, while only $33 \%$ indicated otherwise. 
Table 3: The business is facing Socio-Economic Challenges

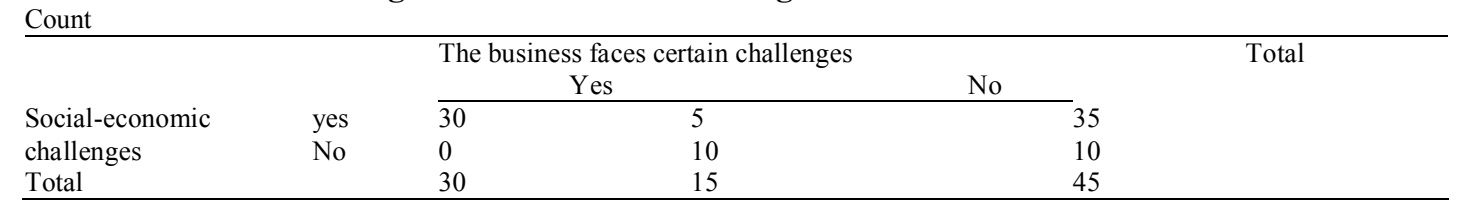

This shows that most of the butchery businesses in Nyamira town were facing various socio-economic challenges explaining their slow in growth rate.

iii. Some of the Socio-Economic Challenges Face

The respondents were asked to note the social- economic challenges they were facing and responses were as in the Table 4.

Table 4: Some of the Socio-Economic Challenges Faced

\begin{tabular}{lcc}
\hline Socio-Economic Challenges Faced & Frequency & Percentage \\
Inadequate capital & 14 & 31 \\
Lack of accounting skills & 9 & 18 \\
Inaccessibility to credit & 12 & 27 \\
High taxation & 4 & 11 \\
Inability/difficulty in paying loan & 3 & 7 \\
Shrinking Markets/Increased competition & 2 & 4 \\
Debt collection & 1 & 2 \\
TOTAL & $\mathbf{4 5}$ & $\mathbf{1 0 0}$ \\
\hline
\end{tabular}

When asked to indicate some of the socio-economic challenges that butchery owners were facing in the running of their businesses, majority of the respondents at 31\%(14) indicated inadequate capital, 27\%(12) mentioned inaccessibility to financial and other credit facilities, $18 \%(9)$ indicated lack of accounting skills, $11 \%(4)$ mentioned high taxation, 7\%(3) indicate inability or difficulty in repaying loan, 4\%(2) mentioned shrinking market/increased competition, while 2\%(1) indicated debt collection and from the study findings, it can be deduced that the major problems facing the butchery owners in Nyamira town were inadequate capital, lack of accounting skills, and inaccessibility to credit facilities.

\section{iv. Received any assistance to help mitigate the challenges}

When asked to indicate whether they had received any assistance to help in mitigating the challenges, majority of the butchery owners at $73 \%$ indicated that they had not receive and assistance, while only $27 \%$ indicated otherwise. This shows that in most cases, the government or the NGOs were not willing to assist the butchery owners in Nyamira town, in terms of loan accessibility and offering entrepreneurial and managerial trainings and this could result into slow growth rate in these business activities.

Table 5: Received any assistance to help mitigate the challenges

\begin{tabular}{lll}
\hline Variables & Frequency & Percentages \\
\hline Yes & 12 & 27 \\
No & 33 & 73 \\
Total & $\mathbf{4 5}$ & $\mathbf{1 0 0}$ \\
\hline
\end{tabular}

The study also sought to find out whether failure to receive assistance to mitigate challenges facing the butchery owners could result into their stunted growth. Out of the 33 respondents that took part in answering this question, majority at $79 \%$ confirmed lack of assistance either financial or managerial could contribute to slow in growth rate, while only $21 \%$ indicated otherwise. 


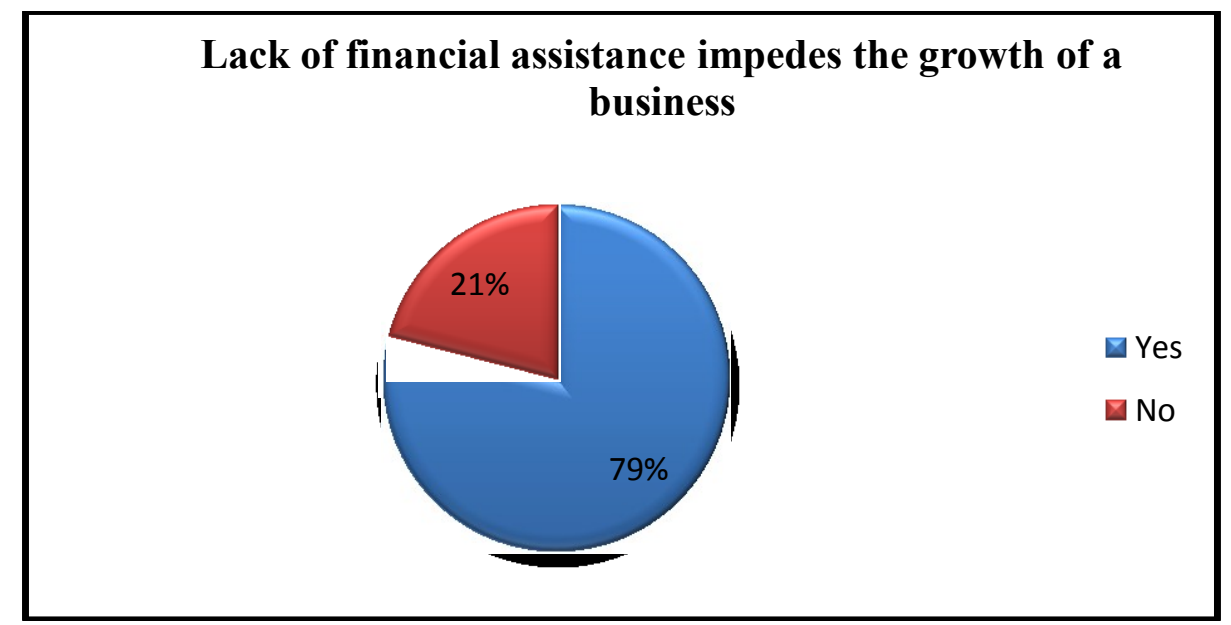

Figure 2: Lack of financial assistance impedes the growth of a business

\section{v. Availability of Change in the Market}

The study sought to find out whether there have been any changes in market since the respondents ventured into the business. According to the study, majority of the respondents at $54 \%$ confirmed that there have been changes, while $46 \%$ indicated that things have remained the way they were. This was imperative in order to investigate whether the respondents were also suffering from strict competition and shrinking of market share as a factor that could affect their growth rate.

Table 6: Availability of Change in the Market

\begin{tabular}{lll}
\hline Variables & Frequency & Percentages \\
\hline Yes & 24 & 54 \\
No & 21 & 46 \\
Total & $\mathbf{4 5}$ & $\mathbf{1 0 0}$ \\
\hline
\end{tabular}

\section{vi. Description of the Change in Market}

When asked to describe the nature of change in the market, majority of the respondents at $57 \%$ indicated that many sellers have come into the market thus offering them much thorough competition and shrinking their market share, $26 \%$ described the change as many buyers has come into the market thus widening the market share, while only $17 \%$ had indicated that his business has become one of the many large sellers (Oligopoly) in the market. However, none $(0 \%)$ of the respondents indicated that the business has emerged as the only seller (Monopoly) in the market.

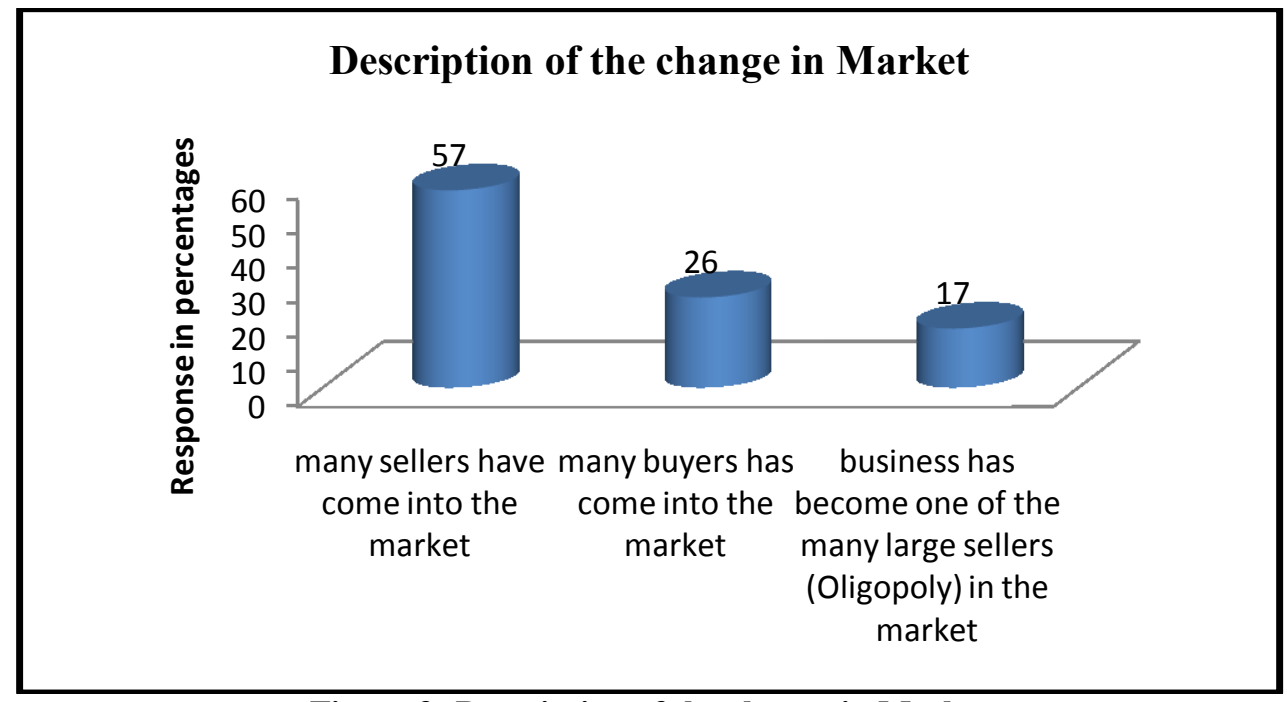

Figure 3: Description of the change in Market

\section{vii. Identification of the New Market}

The study sought to investigate whether the butchery owners of Nyamira Town had identified any new market for their products. This was imperative, as it would help in measuring the growth of these businesses. 


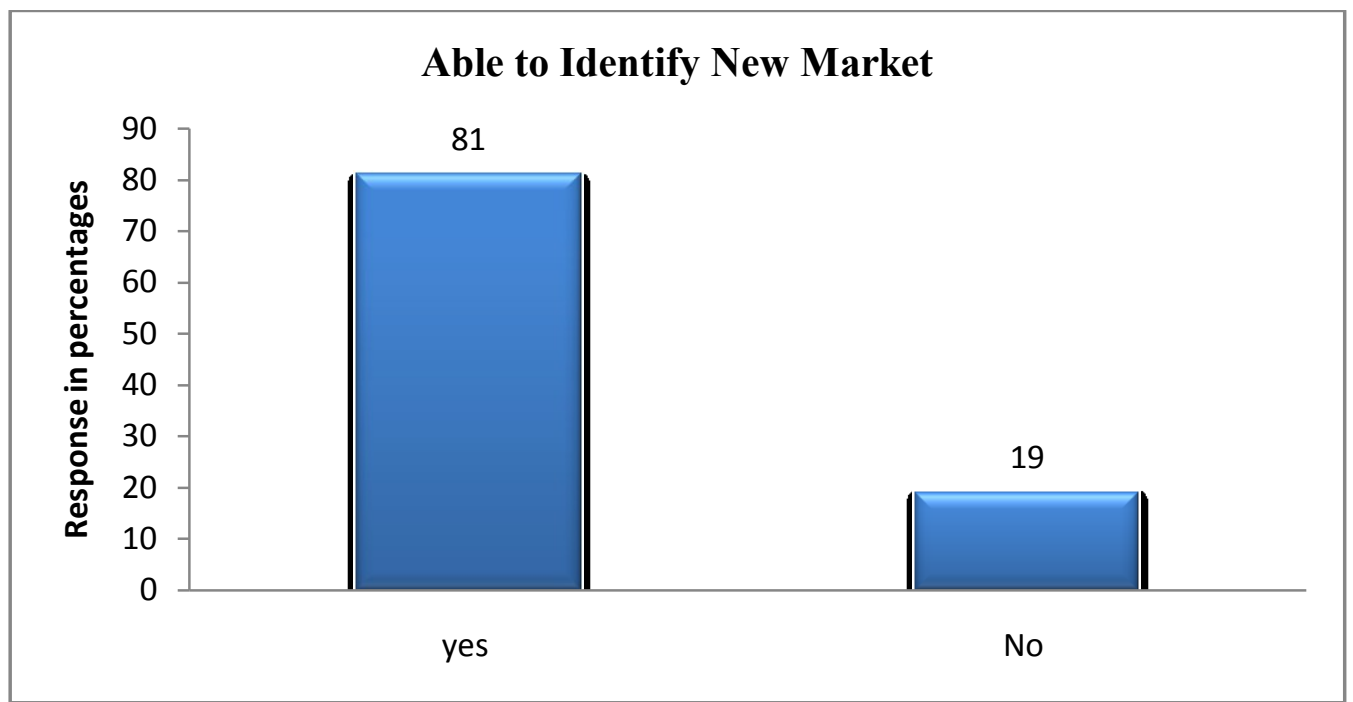

Figure 4: Identification of the New Market

Out of the 45 respondents that took part in answering this question, majority at $81 \%$ indicated that they had not identify any new market, while a paltry $19 \%$ had identified a new market. This shows that the butchery enterprises in this region had not grown in term of market share and were only surviving on the existing market.

viii. Reason for failing to identify the new market

When asked to indicate the reason for failing to identify the new market for their products, majority of the respondents at $36 \%$ cited inadequacy of capital, $29 \%$ indicated inaccessibility to credit facilities, $22 \%$ gave the reason of high taxation, while $13 \%$ mentioned shrinking markets or increased competition. According to this response, financial constraints characterized by inadequate capital, high taxation and inaccessibility to credit facilities were the major impediments for growth of the butchery enterprises in Nyamira town based on identification of new market.

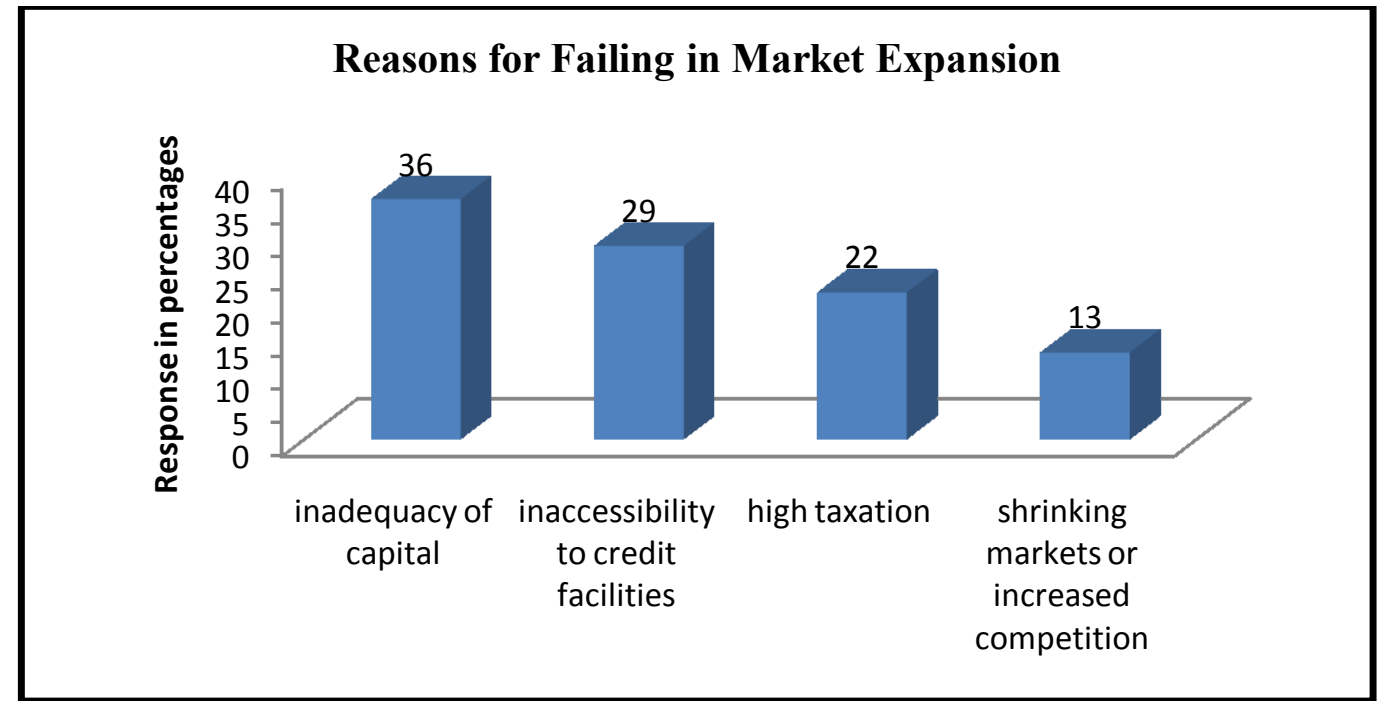

Figure 5: Reason for failing to identify the new market

ix. Loan Accessibility loans and credit facilities from the financial institutions

The study sought to find out whether the butchery owners in Nyamira town could afford loan and other credit facilities from the financial institutions in the area. According to the study findings, majority of the respondents 
Table 7: Loan Accessibility Loans and Credit Facilities from the Financial Institutions

\begin{tabular}{llrrr}
\hline & Loan Accessibility loans and credit facilities from the & Total \\
& & financial institutions & No & 4 \\
Social-economic & Yes & 9 & 36 & 45 \\
challenges & No & 0 & 0 & 45 \\
Total & 9 & 36 & 45 \\
\hline
\end{tabular}

According to the study findings in table 4.8 majority of the respondents 36 accounting for $80 \%$ revealed that they do not access loans or credit facilities from the financial institutions in the region, while a paltry $20 \%$ indicated otherwise.

\section{x. $\quad$ Reasons for lack of Inaccessibility of Loans and Credit facilities}

The butchery owners in Nyamira town were asked to indicate the reasons they could not access the credit facilities and loans. Out of the 36 respondents that answered this question, majority at $36 \%$ cited high interest rate charged by lending institutions, 30\% indicated lack of cash management skills, 20\% mentioned high collateral requirement from lending institutions, while $14 \%$ indicated that loan application procedures are too complicated as shown in figure 6.

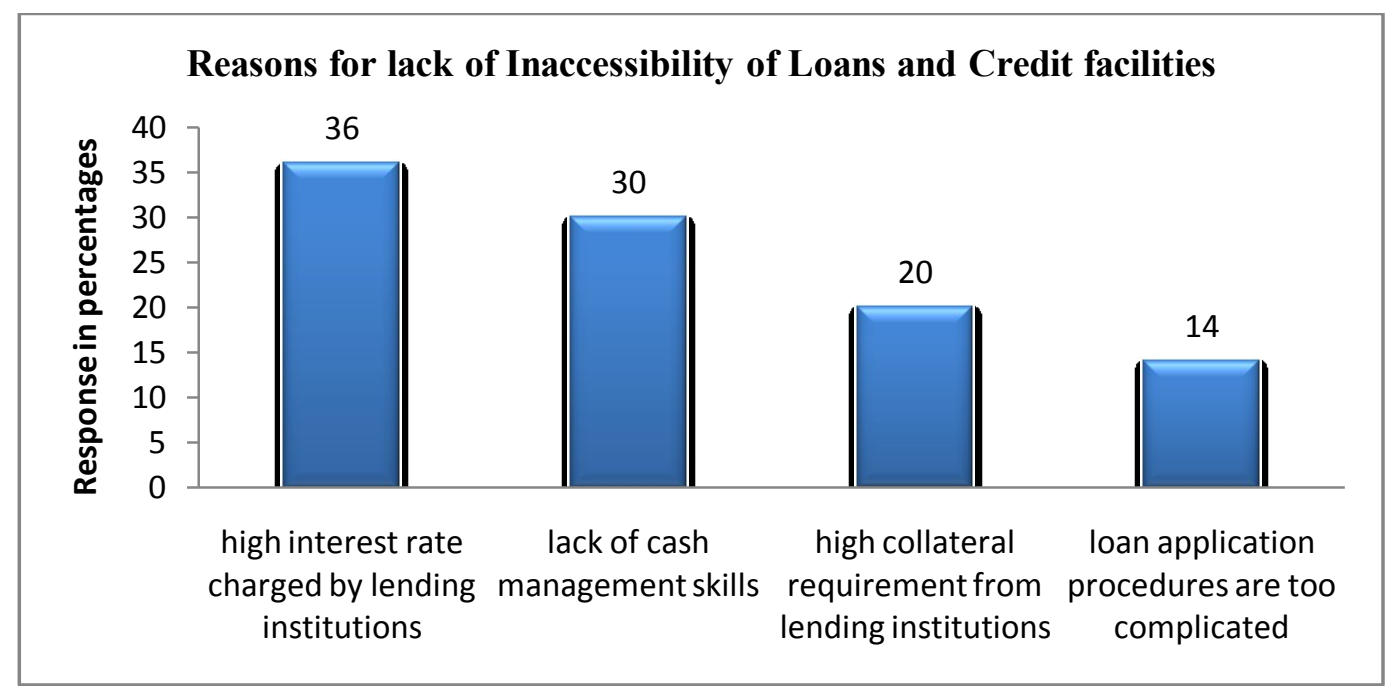

Figure 6: Reasons for lack of Inaccessibility of Loans and Credit facilities

According to the findings, several socio-economic factors affect the growth of butchery enterprise in Nyamira town. For instance, s part of socio-economic factors, respondents were asked to indicate the type of recurring expenses they incurred to a monthly cumulative of between Ksh. 1000-5000. Out of the 45 respondents that took part in answering this question, majority of the respondents at $44 \%$ indicated Family Food and basic needs, 24\% mentioned Business premise rent, 20\% cited Health care, 4\% indicated family house rent, $2 \%$ mentioned entertainment and transport each. This shows that most of the butchery owners are also faced with challenges revolving around their family welfare, which also weigh down their business growth.

When asked to indicate some of the socio-economic challenges that butchery owners were facing in the running of their businesses, majority of the respondents at $31 \%$ indicated inadequate capital, $27 \%$ mentioned inaccessibility to financial and other credit facilities, $18 \%$ indicated lack of accounting skills, $11 \%$ mentioned high taxation, $7 \%$ indicate inability or difficulty in repaying loan, 4\% mentioned shrinking market/increased competition, while $2 \%$ indicated debt collection. From the study findings, it can be deduced that the major problems facing the butchery owners in Nyamira town were inadequate capital, lack of accounting skills, and inaccessibility to credit facilities. Similarly, in his research, Dereje (2008) studied the nature, characteristics, economic performance, opportunities and challenges of MSEs in the food-vending sector based on 125 sample enterprises. The results of the study revealed that the main constraints of these MSEs were shortage of capital, absence of government support, lack of market, lack of credit facilities and high interest rate.

When asked to describe the nature of change in the market, majority of the respondents at $57 \%$ indicated that many sellers have come into the market thus offering them much thorough competition and shrinking their market share, $26 \%$ described the change as many buyers has come into the market thus widening the market share, while only $17 \%$ had indicated that his business has become one of the many large sellers 
(Oligopoly) in the market. However, none $(0 \%)$ of the respondents indicated that the business has emerged as the only seller (Monopoly) in the market. These findings are similar to that of Muteti (2005) who also argued that lack of sufficient market information that faces many of the small scale enterprise poses a great challenge to these enterprises and is also an impediment to their growth. The study also found that majority of the butchery owners in Nyamira town are not able to identify new markets as supported by $81 \%$ of those interviewed, while a paltry $19 \%$ could identified a new market. This shows that the butchery enterprises in this region had not grown in term of market share and were only surviving on the existing market.

When asked to indicate the reason for failing to identify the new market for their products, majority of the respondents at $36 \%$ cited inadequacy of capital, $29 \%$ indicated inaccessibility to credit facilities, $22 \%$ gave the reason of high taxation, while $13 \%$ mentioned shrinking markets or increased competition. According to this response, financial constraints characterized by inadequate capital, high taxation and inaccessibility to credit facilities were the major impediments for growth of the butchery enterprises in Nyamira town based on identification of new market. Fjeldstad et al, 2006 also found that despite the vast amount of trade-related information available and the possibility of accessing national and international databases, many small enterprises continue to rely heavily on private or even physical contacts for market related information hence making them un able to identify new or expand their markets. This is due to inability to interpret the statistical knowledge to interpret and inter connect, small enterprises entrepreneurs need to be supported.

The study sought to find out whether the butchery owners in Nyamira town could afford loan and other credit facilities from the financial institutions in the area. According to the study findings majority of the respondents 36 accounting for $80 \%$ revealed that they do not access loans or credit facilities from the financial institutions in the region, while a paltry $20 \%$ indicated otherwise. When asked to state the reason for this lack of inaccessibility, majority at $36 \%$ cited high interest rate charged by lending institutions, $30 \%$ indicated lack of cash management skills, $20 \%$ mentioned high collateral requirement from lending institutions, while $14 \%$ indicated that loan application procedures are too complicated. These finding supports those of Eshetu and Zeleke (2011) who also found that lack of access to long-term credit for small enterprises forces them rely on very expensive short term loans. There are other financial challenges that face small enterprises. They include the high cost of credit, high bank charges and fees.

\section{Conclusion and Recommendations}

Based on the findings the researcher found that most of butchery operators in Nyamira County were registered sole proprietors and sourced their products from the local market. The study also found that majority of the butchery owners in Nyamira Town face a lot of socio-economic challenges, which could be responsible for their dawdling growth rate. Some of these challenges were found to be inadequate starting and working capital, inaccessibility of both financial and credit facilities to expand their businesses. The study also established that most of the butchery owners were not accessing credit facilities due to high interest rate change, high collateral required and complicated procedures in loan application.

The government through the ministry of trade, finance and planning should use the findings of this research as a platform in designing the policies and measures that when implemented would govern promote the stability and sustainability of not only the butchery micro-enterprises, but other small scale business enterprises. Such policies can include easy loan or grant acquisition for business growth. The Trade Officer and District Development Officer should arrange for seminars and workshops where butchery operators can be advised on how to operate their business in a more economical and profitable manner. The suggestions of policies and measures to enhance the growth of micro-enterprises may also enable not only Nyamira County but entire country in improving its economic development plan, in line with vision 2030 under economic pillar.

\section{References}

[1]. Adil, Y. (2007). Challenges and Constraints of Micro and Small Scale Enterprises in Addis Ababa: The case of 2 Sub-cities' Industrial Zones. MA thesis in Regional and Local Development Studies, RLDS, Addis Ababa University.

[2]. Almas, R., (2009). Meat consumption rate among the social class. Sociological Research Online, 4(3) 282-291

[3]. Amato, P. R. \& S. A. Partridge. (2009). The New Vegetarians: Promoting Health and Protecting Life. NY: Plenum Press

[4]. Bourdieu, P. (2004). Distinction: A Social Critique of the Judgement of Taste, R. Nice (Trans.). Cambridge, MA: Harvard University Press

[5]. Delener, N., (2004). Religious Contrasts in Consumer decision Behaviour patterns: their dimensions and marketing implications. European Journal of Marketing, 28(5) 36-53.

[6]. Dereje L. (2008). Micro and Small Scale Enterprises in the Construction Sector in Addis Ababa: The case of Gullele, Kirkos and Yeka sub-cities. MA thesis in Regional and Local Development Studies. RLDS, Addis Ababa University.

[7]. Elumba, J.D.N. (2008) SMEs/SMIs Centred Industrialization for Inclusive Sustainable Growth in Africa - How can Japan help? Graduate Institute for Policy Studies (GRIPS) Development Forum.

[8]. Eshetu, B. \& Zeleke, W. (2008). Factors that Affect the Long-term Survival of Micro, Small, and Medium Enterprises in Ethiopia. South African Journal of Economics, 10(2):76-81.

[9]. Gancia, G \& Fabrizio, Z. (2005). "Horizontal innovation in the Theory of Growth and Development" pp. 112-70 in Philippe Aghion and Steve Durlauf (eds.).Handbook of Economic Growth, vol.1A Elsevier. 
[10]. Hall, G. (2012). 'Reasons for Insolvency amongst Small Firms'. A Review and Fresh Evidence, Small Business Economics 4(3):237-250.

[11]. Harvey, J., Erdos, G., \& Chalinor, S., (2011). The relationship between attitudes, demographic factors and perceived consumption of meats and other proteins in relation to the BSE crisis: a regional study in the United Kingdom. Health Risk Soc. 3: pp 181-197.

[12]. Hill, C \& Peter K. (2007). Misallocation and manufacturing TFP in China and India", Mimeo. Stanford University.

[13]. International Labour Organization (2008). Factors affecting Women Entrepreneurs in Micro and small Enterprises in Kenya, A primary Research report. International Labour Office, Geneva and private sector department (OPSD), Africa Development Bank (AFDB) (Tunis)

[14]. Jitahada (2010). Kenya‘s National Business Plan Competition Report. Published by KIM and the Ministry Of Industrialization.

[15]. Karugia, J. T. (1990) Competition and Efficiency in Beef Retailing in o Metropolitan Area: The Case of The City of Nairobi. Unpublished M. Sc. Thesis, University of Nairobi,

[16]. King, M \& McGrath, J (2002) "Finance Entrepreneurship, and Growth: Theory and Evidence", Journal of Monetary Economics, 32(3):513-542.

[17]. Kiraka, R. (2009) Innovative Private Sector Development Instruments - an African Perspective for investing in the development of Small and Medium Enterprises. Working Paper 01/2009. ICEP.

[18]. Kohl, D.M. (2001). Megatrends in Agriculture: Implications for the Food Distribution System Journal of Food Distribution Research. March 32(1)1-4.

[19]. Kombo, D. K., \& Delno, L. A. T. (2006). Proposal and Thesis Writing: An Introduction. Nairobi: $\quad$ Pauline's publications Africa.

[20]. Kothari, C.R. (2003). Research Methodology: Methods and Techniques. New York: New Delhi K.K. Gupta.

[21]. Kothari, C.R. (2005). Research Methodology: Methods and Techniques (4 ${ }^{\text {th }}$ Ed.) Wiswaprakashan: New Age International (P) Ltd, publishers, Dharmesh Printers, Delhi.

[22]. Lazear, E. P. (2005) "Entrepreneurship", Journal of Labour Economics, 23(4) 649-80.

[23]. Lee, C. (2004) "The Determinants of Innovation in the Malaysian Manufacturing Sector: An Econometric Analysis at Firm level", ASEAN Economic Bulletin Dec-01-04

[24]. Marcus, E. (2008). Vegan: The New Ethics of Eating. Ithaca, NY: McBooks Press

[25]. Melina, V., B. Davis \& V. Harrison. (2005). Becoming Vegetarian: The Complete

a. Guide to Adopting a Healthy Vegetarian Diet. Summertown, TN: Book

b. Publishing Co.

[26]. McCormick, D (2013). "Risk and Firm Growth: The dilemma of Nairobi's Small - Scale Manufacturers". Discussion paper No. 291, Nairobi: IDS University Of Nairobi.

[27]. McMahon, R. (1998). "Stage models of SME growth reconsidered”. In Schmitt Degenhardt, S., Stamm, A., Zehdnicker, M., (2002). The Growth Gap: A small enterprise phenomenon. El Salvador: ANEP/GTZ.

[28]. Mugenda, O.M., \& Mugenda, A.G. (2003).Research Methods: Quantitative and Qualitative Approaches. Nairobi: African Centre for Technology Studies (ACTS).

[29]. Mulugeta Y. F. (2011). The Livelihoods Reality of Micro and Small Enterprise Operators: Evidences from Woreda One of Lideta Sub-city, Addis Ababa. Master's Thesis Submitted to the Center for Regional and Local Development Studies, Graduate School of Development Studies, Addis Ababa University, Ethiopia. Unpublished Master's Thesis.

[30]. Musaiger, A.O., (2012). Socio-cultural and economic factors affecting food consumption patterns in the Arab countries. Journal of the Royal Society for the Promotion of Health, 113 (2) 68-74.

[31]. Muteti, P. (2005) "Measurements of Family Involvement; Across National Study of Managers", Journal of Cross -cultural Psychology 21(2):232-48.

[32]. Nicholas, L. (2006). Support for growth-oriented women entrepreneurs in Ethiopia, Kenya and Tanzania: An Overview Report, Programme on Boosting Employment through Small Scale Enterprise Development Job Creation and Enterprise Department and Marked Structure", pp 1059-1117 Schmanalensee and R. Wiling (Eds) Handbook of Industrial Organization Volume 11.

[33]. Nachmias, C. \& Nachmias, S. D. (2005). Research Methods in Social Sciences (5 $5^{\text {th }}$ Ed). London: Arnold.

[34]. OECD, (2004). Promoting Entrepreneurship and innovative SMES in a global Economy: Towards a more responsible and inclusive globalization, Instabul, Turkey 3-5 organization for Economic Cooperation and Development. Paris: [Online] Available: http://www.oecd-instanbul.sme2004.org

[35]. Organization of American States (OAS) (2001).Bogota Manual: Standardization of Technological Innovation in Latin American and Caribbean Countries, Organization of American States.

[36]. Orodho, J.A (2005), Elements of Education and Social Sciences Research Methods. Bureau of Educational Research. Institute of Research and Development. Kenyatta University, Nairobi Kenya

[37]. Orser, B. J., Hogarth-Scott, S. and Riding, A.L., (2000). "Performance, Firms Size and Management problem solving (x)". Journal of small Business Management 38.4 (2000): 42. [Online] Available: http://www.questia.com/pm.qst?a-o\&d=5001102764>.n.

[38]. Owuor, G. \& Bebe, B. (2009). What Influences Price Efficiency in Indigenous Chicken Markets in Africa? Evidence from smallholder farmers in Kenya, 111 EAAE-IAAE Seminar 'small farms: Decline or Persistence' University of Kent, Canterbury, UK 26th -27th Jun 2009.

[39]. Papadiki, E \& Chami, B. (2002). Growth Determinants of Micro-Businesses in Canada. Small Business Policy Branch Industry Canada.

Available:Strategies.ic.gc.ca/epic/internet/insbrp,ppe.nsf/vwapj/growth_determinants.pdf/\$FILE/growth_determinants.pdf.

[40]. Paul I. \& Rahel W. (2010). Growth Determinants of Women-operated Micro and Small Enterprises in Addis Ababa. Journal of Sustainable Development in Africa.

[41]. Pettinger, C., Holdsworth, M., \& Gerber, M., (2004). Psycho-social influences on food choice in Southern France and Central England, Appetite, 42(3), pp 307-316.

[42]. Republic of Kenya (2005).Sessional paper No. 2 of 2005 on Development of micro and small Enterprises for Wealth and Employment Creation for Poverty Reduction, Government Kenya Policy Document.

[43]. Robbins, J. (2007). Diet for a New America. Walpole, NH: Still point Publishing. American Dietetic Association (ADA). (2009).Vegetarian diets [on-line]. http://eatright.org (last accessed January 22nd, 2012).

[44]. Santon, J.V., (2000). The Role of Agribusiness in Development: Replacing the Diminished Role of the Government in Raising Rural Incomes, Journal of Agribusiness, 18.2 (spring 2000):173-187.

[45]. Schwab, D .P (2005). Research Methods of Organizational Studies (2 ${ }^{\text {nd }}$ ed) Lawrence Erlbaum, Mahwah, NJ, USA.

[46]. Sekeran, U. (2003), Research Methods for Business; A Skill Building Approach, $4^{\text {th }}$ ed., John Wiley \& Sons, New York, USA. 
[47]. SIEID, (2004). "Synthesis Report. Characteristics of firms that grow from small to medium size". Presented to industrial research Assistance Program, National Research Council of Canada, April 30, 2004.

[48]. Staines, A. (2005). "Double Trouble": The Growth of Small \& Medium-Sized Enterprises in Small Island Economies.

[49]. Stokes, D \& Wilson, N. (2010). Small Business Management and Entrepreneurship. 6th Ed. United Kindom. SOUTH-WESTERN.

[50]. Stokes, D. (2005). Small Business Management: An Active - Learning approach. (2nd ed). London: AP Publication Ltd.

[51]. Verbeke, W., (2005). Consumer acceptance of functional foods: socio-demographic, cognitive and attitudinal determinants, Food Quality and Preference, 16, pp 45-57.

[52]. Wachira, N. (2006). "Money: Hanging up at Telkom". In Daily Nation, 13th April, p.8, Nairobi: Nation Media Publishers.

[53]. Wanjohi \& Mugabe (2008) Entrepreneurship Ideas an Action South - Western of Thomson Learning inc. $3^{\text {rd }}$ edition

[54]. Wolverton, M. L. (2009). Research design, hypothesis testing, and sampling. Appraisal Journal, 77(4), $370-382$.

[55]. Workneh F. (2007). The Constraints of Micro and Small Scale Enterprises in Addressing Employment Opportunity: The case of Kolfe Keraneo Sub-city, Addis Ababa. MA Thesis in Regional and Local Development Studies. RLDS, Addis Ababa University.

[56]. World Bank. (2004). "Small and Micro Enterprises". World Bank Group Review of Small Business Activities. Washington, DC: World Bank

[57]. Zikmund, W.G. (2003).Business Research Methods with Infotrac, ( $7^{\text {th }}$ ed) Thomson, South-Western College Pub, USA. 